\title{
AN EMPIRICAL EXAMINATION OF THE RELATIONSHIP BETWEEN THE BACKGROUND CHARACTERISTICS OF THE CEO AND OVERALL CORPORATE REPUTATION
}

\author{
Peter A. Stanwick \\ Sarah D. Stanwick \\ Auburn University \\ Auburn, AL
}

\begin{abstract}
This paper examines the relationship between the overall corporate reputation of an organization and the background characteristics of the Chief Executive Officers (CEOs) across twenty one major industry classifications. Four background characteristics are examined: (1) age, (2) tenure with the company, (3) tenure as CEO, and (4) functional background (career path). These characteristics are explored by examining the overall corporate reputation of the organization through a proxy, the Fortune Corporate Reputation Index. Drawing on past research in the area of background characteristics (Hambrick and Mason, 1984) and corporate reputation (Fombrun and Shanley, 1990), hypotheses were tested which examined the background characteristics of CEOs and the company's overall corporate reputation. The results of this paper show that, in general, the CEO's background characteristics impact the level of overall corporate reputation of the firm. The type of functional background of the CEO has a significant positive impact on the level of overall corporate reputation. Over a four year time period (1990 to 1994), age, tenure with the company, and tenure as $C E O$ were negatively related to the overall corporate reputation of organizations that retained their $C E O$. For firms that had replaced the CEO, a positive relationship between overall corporate reputation and tenure with the company and age was discovered.
\end{abstract}

\section{Introduction}

Fombrun and Shanley (1990) state that a firm's corporate reputation can send a strong signal of how well a company is performing compared with other firms in the industry. A strong favorable corporate reputation demonstrates the firm's ability to properly position the firm's products and the effective implementation of the firm's strategies. Both Caves and Porter (1977) and Wilson (1985) argue that a favorable corporate reputation can yield excess financial returns for firms by generating a competitive advantage by differentiating themselves from their competitors. A critical component in the development of a competitive advantage is the decision making by the top level management within the organization in- 
cluding the CEO. The CEO is considered a dominant force in the decision making process of an organization (Beatty and Zajac, 1987). Dalton and Kesner (1985) state that the CEO is the central focal point within the organization. Therefore, the purpose of this study is to the examine the relationship between the overall corporate reputation of a firm and the background characteristics of the CEO.

This study examines the relationship between background characteristics which include: (1) age, (2) functional background (career path), (3) tenure with the company, and (4) tenure as CEO with the company. These characteristics are compared with the organization's Fortune Corporate Reputation Index.

\section{Theoretical Framework and Hypothesis Development}

The underlying theoretical framework is based on a seminal work by Hambrick and Mason (1984). Hambrick and Mason (1984) proposed that specific characteristics of top level managers influenced the type of strategic choices made by the firm. As a result, it is proposed in this study that the background characteristics of the CEO can impact the "strategy" of developing a favorable overall corporate reputation. Hambrick and Mason (1984) present a number of observable upper echelon characteristics which include: functional track, age, and tenure.

\section{Functional Background}

Hambrick and Mason (1984) separate functional tracks into three different segments: (1) output functions, (2) throughput functions, and (3) peripheral functions. Executives with output functions (marketing, sales, and product research and development) are expected to emphasize growth, product innovation, and the development of new market opportunities.

Chaganti and Sambharya (1987) discovered that firms that were proactive in their approach to new product and new market development had a higher level of executives who had a marketing and/or research and development background. Thomas, Litschert, and Ramaswamy (1991) also discovered that high performing proactive firms had CEOs with an output functional background. CEOs with an output functional background are committed to the belief that an aggressive proactive strategic philosophy will yield high performance results. Output based CEOs will be more likely to be not only committed, but are also more likely to convert product innovation efforts into actual product innovations (Barbosa, 1985). Barbosa (1985) discovered that CEOs with marketing experience were more likely to transfer research and development innovations into new products. Barbosa (1985) asserts that firms with a CEO who has a marketing background are more likely to: be creative, be market driven, and believe in growth opportunities for the firm.

CEOs with an output functional background focus on the aggressive expansion of the firm based on examining new product and/or market related opportunities. The CEOs believe that the long term success of the firm is based on incor- 
porating a "pioneering" perspective by embracing new opportunities and new technologies. They believe that a favorable overall corporate reputation could lead to a competitive advantage in the marketplace (Caves and Porter, 1977; Wilson, 1985). These CEOs will encourage creative and market driven solutions which would result in favorable overall corporate reputations.

It is also posited that CEOs with a throughput functional background (production, process engineering, or accounting) are concerned with improving the efficiency of the overall organization by such actions as automation and the improvement of plant and equipment. Thomas, Litschert, and Ramaswamy (1991) found that firms that focused on stability and efficiency had CEOs who had a throughput functional background. Therefore, the CEOs are not as proactive in their strategic focus. Strategic issues are classified based on a focus of efficiency. As a result, it is expected that firms with a throughput CEO will have less favorable corporate reputations than CEOs with an output functional background.

Peripheral functional background (law and finance) are functions that are not directly involved with the organization's core activities. Song (1982) found that CEOs with a peripheral functional background focused on growth opportunities by acquiring firms that were unrelated to the firm's core business. Hambrick and Mason (1984) assert that peripheral functional CEOs do not focus on strategies that relate to the core operations of the firms (i.e., new product/market development or efficiency issues) since they do not have the necessary "hands on" experience in their core business. As a result, CEOs with a peripheral functional background are more likely to have a reactive instead of a proactive stance concerning strategic issues. Therefore, the development of new products which would incorporate new market opportunities would not be developed in a firm with a peripheral CEO nor would the integration of efficiency issues take place as they would with a firm that has a throughput CEO. As a result, it is expected that firms with a CEO with a peripheral functional background will have the least favorable overall corporate reputations. Therefore, the following hypothesis is empirically tested in this study:

Hypothesis 1: Firms with CEOs with a peripheral functional background will have the least favorable overall corporate reputations.

\section{CEO Tenure}

Previous research on the relationship between the CEO's age, tenure, and decision making have yielded conflicting results. Some studies have shown that CEOs that are younger and have less tenure are more flexible and proactive in their decision making (Hambrick and Fukutomi, 1991; Miller, 1991). Hambrick and Fukutomi (1991) state that there are certain seasons of tenure for a CEO. For the first two years of tenure, the CEO will make organizational adjustments to 
match the CEO's vision. Up to the first four years of tenure, the CEO will experiment with new ideas as a re-configuration of the organization occurs. After this relatively short period of time, the CEO becomes further committed to the existing paradigm. As a result, a status quo belief becomes firmly entrenched with a high level of rigidity and commitment to the established policies and procedures of the organization. Therefore, as the tenure of the CEO increases, so does the resistance to change by the CEO of the current operations of the organization (Finkelstein and Hambrick 1990). Finkelstein and Hambrick (1990) also discovered that there is a positive relationship between the tenure of the CEO and general strategic philosophy of other firms in the industry. Chaganti and Sambharya (1987) examined the relationship between tenure and strategic focus and discovered that CEOs with a long length of tenure focused on stability and efficiency issues, while CEOs with less tenure concentrated on more proactive strategies including new product and new market development.

The age of the CEO or the 'tenure of life' (Finkelstein and Hambrick, 1996) has also been empirically examined and has shown the same inverse relationship with pro-activeness and flexibility that was shown with tenure with the organization. Vroom and Pahl (1971) found a negative association between age and risk taking in the decision making process. This finding was supported in subsequent work which demonstrated an inverse relationship between age and product/market innovation strategies (Thomas et al., 1991) and strategic change (Grimm and Smith, 1991; Wiersema and Bantel, 1992). Therefore, it is expected that tenure would also have an inverse relationship with overall corporate reputation of the organization.

Based on the CEO seasons of tenure presented by Hambrick and Fukutomi (1991), a four year time period was selected. Hambrick and Fukutomi (1991) categorize the tenure of the CEO into 5 major seasons which are: Response to Mandate ( 1 to 2 years), Experimentation (1 to 2 years), Selection of an Enduring Theme ( 1 to 2 years), Convergence ( 3 to 5 years), and Dysfunction (all remaining years). The four year time frame allows the CEO to potentially go into the fourth season (Selection of an Enduring Theme). Therefore, this would reduce the probability that the sample would just demonstrate the strategic actions of new CEOs.

Based on the work of Miller (1991) and Hambrick and Fukutomi (1991), it is proposed that over a specific time period (1990 to 1994), there will be an inverse relationship between age and the overall corporate reputation of the organization. It is expected that younger CEOs will implement strategic activities that will enhance the overall corporate reputation of the firm.

In addition, it is proposed that within a specific time period (1990 to 1994) firms with CEOs with less tenure in the organization and less tenure as CEO will have more favorable overall corporate reputations since the CEOs are less entrenched in the organization's overall beliefs (Hambrick and Fukutomi, 1991). Since a change in CEO could occur within this four year time frame, the sample will be analyzed based on whether there has been a succession of the CEO or not. It is expected that the relationship between the characteristics will be the 
same regardless of whether or not a CEO succession has occurred. As a result, the following hypotheses are empirically tested in this study:

Hypothesis 2: Within a certain time period (1990 to 1994), firms with younger $C E O$ s will have more favorable overall corporate reputations.

Hypothesis 3: Within a certain time period (1990 to 1994), firms with CEOs with less tenure with the organization will have more favorable overall corporate reputations.

Hypothesis 4: Within a certain time period (1990 to 1994), firms with $C E O s$ with less tenure as the CEO with the organization will have more favorable overall corporate reputations.

In addition to examining the relationship between the background characteristics of the CEO and the overall corporate reputation of the organization, this paper examines these relationships across different industries. Cross industry comparisons have been largely ignored in previous research on overall corporate reputations.

\section{Sample Selection}

\section{Methodology}

\section{For Hypothesis 1:}

The sample of firms for years 1990 and 1994 included in this study meet the following criteria:

1. The firm must be ranked in the Fortune Corporate Reputation Index.

2. The firm must be listed in Business Week's Corporate Elite so that the background characteristics of the CEOs can be examined.

3. The firm must be listed in Fortune's top 1000 companies in order to obtain the firm's industry classification.

This criteria resulted in the selection of 235 firms in 1990 and 267 firms in 1994.

\section{For Hypotheses 2-4:}

In addition,

1. The same criteria as stated in I.

2. The firms must be in both the 1990 and the 1994 sample.

3. The firms are separated into two categories: a) firms that retain the same CEO and, b) firms that had a new CEO.

This resulted in the selection of 169 firms in which 114 firms had the same CEO and 55 firms had a CEO succession. 


\section{Overall Corporate Reputation}

Overall corporate reputation is based on the Fortune Corporate Reputation Index. This index employs over 8,000 executives and outside industry experts who evaluate organizations within their own industry on eight different variables on a scale from zero (poor) to ten (excellent). The eight attributes are: (1) quality of management, (2) quality of products or services, (3) innovativeness, (4) longterm investment value, (5) financial soundness, (6) ability to attract, develop, and keep talented people, (7) wise use of corporate assets, and (8) responsibility to the community and the environment. Based on the ranking of these eight variables, an overall reputation number is derived.

Previous research has used the Fortune Corporate Reputation Index to measure the relationship between overall corporate reputation and various accounting, institutional, and strategic signals presented by the firm (Fombrun and Shanley, 1990). In addition, previous research has also examined the relationship between corporate reputation and prior firm performance using the Fortune Corporate Reputation Index (Hammond and Slocum, 1996). Previous studies have also supported the validity of this instrument by using all or part of the Fortune Corporate Reputation Index as a measurement of corporate social performance (Hoft, Hunger and Shrader, 1991; McGuire, Sundgren and Schneeweiss, 1988; Thomas and Simerly, 1994; Wokutch and Spencer, 1987).

\section{Functional Background}

Functional background was coded based on the description given in Business Week's Corporate Elite. After examining the description of the functional background, it was evident that numerous CEOs had multiple functional backgrounds which could not be coded into only one categorization (output, throughput, or peripheral). In addition, the 1990 and 1994 sample did not yield enough observations of CEOs with solely peripheral functional background (90 in 1990 and 116 in 1994) to identify significant differences. As a result, the functional backgrounds were grouped into two major categories which are: CEOs whose functional background included peripheral training and CEOs that did not. As was stated previously, peripheral functional background did not supply the CEO with the necessary "hands-on" experience to become actively involved in the strategic decisions about the core businesses of the firm. Even though the CEOs may have additional experience in other functional areas, this lack of grounded experience limits their ability to envision the potential benefits of new product/ market development and efficiency gains that would enhance overall corporate reputations. As a result, if the CEO had a functional background in output or throughput or a combination of the two, they were classified into the non-peripheral group. If the CEOs had functional backgrounds in peripheral or a combination of peripheral and throughput or output, they were classified as having a peripheral functional background. In the 1990 sample, 118 CEOs were classified as having a non-peripheral functional background and 117 were classified as having 
a peripheral functional background. In the 1994 sample, 127 CEOs were classified as having a non-peripheral functional background and 140 CEOs were classified as having a peripheral functional background.

\section{Industry Classifications}

The industries were classified based on the categorizations used in the Forbes 500 listing.

\section{Results}

A total of 235 firms in 1990 and 267 firms in 1994 were examined. The results showed that firms with favorable overall corporate reputations have a higher incidence of peripheral functional background CEOs which is the opposite direction of the relationship that was proposed in Hypothesis 1. In addition, when the CEOs remain the same over the four year time period, firms with favorable overall corporate reputations had a higher incidence of younger CEOs, with less tenure within the organization and less tenure as CEO which supports Hypotheses 2 through 4. However, the relationship showed an opposite pattern when a new CEO took over during the four year time period. Table 1 provides descriptive statistics for both samples of firms.

Table 1

Descriptive Statistics

\begin{tabular}{lrrrr}
\hline & Mean & Std Dev & Minimum & Maximum \\
\hline 1990 Sample & & & & \\
REP90 & 6.36 & 0.92 & 3.10 & 8.86 \\
AGE & 57.58 & 6.26 & 41.00 & 92.00 \\
TEN & 25.67 & 11.52 & 1.00 & 54.00 \\
TENCEO & 7.41 & 7.60 & 0.50 & 45.00 \\
& & & & \\
1994 Sample & & & & \\
REP94 & 6.48 & 0.81 & 3.65 & 8.65 \\
AGE & 57.29 & 5.80 & 38.00 & 79.00 \\
TEN & 24.67 & 11.49 & 1.00 & 55.00 \\
TENCEO & 8.44 & 7.69 & 1.00 & 55.00 \\
\hline
\end{tabular}

Index:

REP90 = Fortune Corporate Reputation Index for 1990

REP94 = Fortune Corporate Reputation Index for 1994

$\mathrm{AGE}=\mathrm{Age}$ of the $\mathrm{CEO}$

TEN $=$ Number of years of tenure in the company by the CEO

TENCEO $=$ Number of years of tenure as CEO 
The mean of the Fortune Corporate Reputation Index was 6.36 in 1990 and 6.48 in 1994. In addition, this table shows that in 1990, the CEOs average age was 57.58 years, tenure with the company was 25.67 years, and tenure as CEO was 7.41 years. The same information for 1994 indicated that the average age was 57.29 years, tenure with the company was 24.67 years, and tenure as CEO was 8.44 years.

Regression analysis was used to examine the relationship between the firm's overall corporate reputation and the background characteristics of the CEO of the firm. Using regression analysis, the results showed that there were indeed strong relationships between the background characteristics of the CEO and the level of overall corporate reputation. In the 1990 sample, the results showed a significant positive relationship between age and overall corporate reputation $(t=2.09$, $p<.0379)$ and tenure as CEO and overall corporate reputation $(t=2.73, p<.0069)$ as indicated in Table 2.

Table 2

Regression Results for Overall Corporate Reputation

All Firms in the 1990 Sample

Dependent Variable $=$ REP90

$\begin{array}{lrcccc}\text { Source } & \text { DF } & \text { Sum of Square } & \text { Mean Square } & \text { F Value } & \text { Prob }>\text { F } \\ \text { Model } & 7 & 13.1701 & 1.8814 & 2.26 & 0.0302^{*} \\ \text { Error } & 227 & 188.5911 & 0.8307 & & \\ \text { Total } & 234 & 201.7612 & & & \end{array}$

R-Square $=0.0652$

$\begin{array}{lcccc}\text { Variable } & \begin{array}{c}\text { Parameter } \\ \text { Estimate }\end{array} & \begin{array}{c}\text { Standard } \\ \text { Error }\end{array} & \begin{array}{c}\text { T for Ho: } \\ \text { Parameter=0 }\end{array} & \text { Prob>T } \\ \text { INTERCEPT } & 2.3723 & 1.6818 & 1.41 & 0.1597 \\ \text { TENCEO } & 0.4683 & 0.1717 & 2.73 & 0.0069^{*} \\ \text { AGE } & 0.0609 & 0.0291 & 2.09 & 0.0379^{*} \\ \text { TEN } & 0.0898 & 0.0680 & 1.32 & 0.1877 \\ \text { AGE*TEN } & -0.0012 & 0.0011 & -1.10 & 0.2739 \\ \text { TENCEO* AGE } & -0.0069 & 0.0027 & -2.55 & 0.0113^{*} \\ \text { TENCEO* TEN } & -0.0109 & 0.0052 & -2.10 & 0.0370^{*} \\ \text { TENCEO*AGE*TEN } & 0.0001 & 0.0000 & 1.97 & 0.0495^{*}\end{array}$

*Significant at $\mathrm{p}=0.05$

Index:

REP90 $=$ Fortune Corporate Reputation Index for 1990

$\mathrm{AGE}=$ Age of the CEO

TEN = Number of years of tenure in the company by the CEO

TENCEO $=$ Number of years of tenure as CEO 
In addition, there were significant interactions between tenure as CEO and age and tenure, and a significant three way interaction among all three of the variables, also as indicated in Table 2.

Table 3 presents the results from examining overall corporate reputations of firms with a CEO who was classified as having a peripheral functional background.

Table 3

Regression Results for Overall Corporate Reputation for Firms with a CEO with a Peripheral Functional Background - 1990 Sample

Dependent Variable $=$ REP90

$\begin{array}{lrcccc}\text { Source } & \text { DF } & \text { Sum of Square } & \text { Mean Square } & \text { F Value } & \text { Prob>F } \\ \text { Model } & 7 & 16.0056 & 2.2865 & 2.52 & 0.0192^{*} \\ \text { Error } & 109 & 98.7721 & 0.9061 & & \\ \text { Total } & 116 & 114.7778 & & & \end{array}$

R-Square $=0.1394$

$\begin{array}{lcccl}\text { Variable } & \begin{array}{c}\text { Parameter } \\ \text { Estimate }\end{array} & \begin{array}{c}\text { Standard } \\ \text { Error }\end{array} & \begin{array}{c}\text { T for Ho: } \\ \text { Parameter=0 }\end{array} & \text { Prob>T } \\ \text { INTERCEPT } & -1.0487 & 2.5825 & -0.41 & 0.6855 \\ \text { TENCEO } & 0.5040 & 0.2878 & 1.75 & 0.0827 \# \\ \text { AGE } & 0.1210 & 0.0464 & 2.61 & 0.0104^{*} \\ \text { TEN } & 0.2038 & 0.1061 & 1.92 & 0.0575 \# \\ \text { AGE*TEN } & -0.0032 & 0.0018 & -1.78 & 0.0780 \# \\ \text { TENCEO* AGE } & -0.0070 & 0.0049 & -1.43 & 0.1546 \\ \text { TENCEO* TEN } & -0.0139 & 0.0072 & -1.93 & 0.0558 \# \\ \text { TENCEO* AGE*TEN } & 0.0001 & 0.0001 & 1.72 & 0.0891 \#\end{array}$

\#Significant at $p=0.10$

*Significant at $p=0.05$

Index:

REP90 = Fortune Corporate Reputation Index for 1990

$\mathrm{AGE}=\mathrm{Age}$ of the $\mathrm{CEO}$

TEN = Number of years of tenure in the company by the CEO

TENCEO $=$ Number of years of tenure as CEO

Results for firms with a CEO classified as having a peripheral career path had a significant positive relationship with age and overall corporate reputation $(t=2.61$, $\mathrm{p}<.0104)$, tenure and overall corporate reputation $(t=1.92, \mathrm{p}<.0575)$, and tenure as $\mathrm{CEO}$ and overall corporate reputation $(t=1.75, \mathrm{p}<.0827)$. In addition, the results yielded significant interactions between age and tenure, and tenure as CEO and tenure with 
the firm. A significant three way interaction between the three variables was also present. Therefore, the results show a significant relationship in the opposite direction than was proposed in Hypothesis 1. Firms with a favorable overall corporate reputation had a higher incidence of peripheral functional background CEOs. The regression analysis for the 1994 sample did not yield significant results.

Correlation analysis (Tables 4 and 5) was used to examine the strength of the relationship between each of the variables examined in this study (reputation, age, tenure, tenure as CEO) from the time period 1990 to 1994 across all 21 industries. The firms were categorized based on whether the firm had replaced the CEO or not within the same period. For the 114 firms that had the same CEO from 1990 to 1994 , there were a number of significant correlations.

\section{Table 4}

Correlation Analysis Results

Change from 1990 to 1994 Same CEOs

\begin{tabular}{|c|c|c|c|}
\hline \multicolumn{4}{|c|}{ INDUSTRY = Computers/Communications } \\
\hline & AGE & TEN & TENCEO \\
\hline \multirow[t]{2}{*}{ CREP94 } & -0.5703 & -0.7532 & -0.0808 \\
\hline & 0.1399 & $0.0310^{*}$ & 0.8491 \\
\hline
\end{tabular}

INDUSTRY $=$ Consumer Durables

$\begin{array}{lllr}\text { CREP94 } & \text { AGE } & \text { TEN } & \text { TENCEO } \\ & 0.1639 & 0.7445 & 0.4296 \\ & 0.6509 & 0.0135^{*} & 0.2153\end{array}$

INDUSTRY $=$ Consumer Nondurables

$\begin{array}{cccr} & \text { AGE } & \text { TEN } & \text { TENCEO } \\ \text { CREP94 } & -0.5825 & -0.0531 & 0.1770 \\ & 0.0998 \# & 0.0819 & 0.6485\end{array}$

INDUSTRY $=$ Transportation

$\begin{array}{llcc} & \text { AGE } & \text { TEN } & \text { TENCEO } \\ \text { CREP94 } & 0.6594 & -0.6725 & -0.9980 \\ & 0.5416 & 0.5304 & 0.0396^{*}\end{array}$

INDUSTRY $=$ Travel

\begin{tabular}{lccc} 
& AGE & TEN & TENCEO \\
CREP94 & -0.1316 & -0.9998 & -0.4488 \\
& 0.9160 & $0.0108^{*}$ & 0.7037 \\
\hline
\end{tabular}

\#Significant at $p=0.10$

*Significant at $\mathrm{p}=0.05$

Index:

CREP94 = Change in Fortune Corporate Reputation Index from 1990 to 1994

$A G E=A g e$ of the CEO

TEN = Number of years of tenure in the company by the CEO

TENCEO $=$ Number of years of tenure as CEO 
From the time period 1990 to 1994 , there was an inverse relationship between tenure with the firm and the change in overall corporate reputation in the computer/communications and travel industry and a positive relationship in the consumer durables industry. There was an inverse relationship between age and the change in overall corporate reputation in the consumer nondurables and the health industry. There was an inverse relationship between tenure as CEO and the change in overall corporate reputation in the transportation industry. Therefore, Hypotheses 2 through 4 are supported. Firms with a favorable overall corporate reputation who have the same CEOs for the four year time period are younger and have less tenure as CEO and less tenure within the organization. There were also significant correlations for the 55 firms that did change their CEO within the time period 1990 to 1994.

Table 5

Correlation Analysis Results Change from 1990 to 1994 Different CEOs

\begin{tabular}{|c|c|c|c|}
\hline \multicolumn{4}{|c|}{ INDUSTRY = Capital Goods } \\
\hline & AGE & TEN & TENCEO \\
\hline \multirow[t]{2}{*}{ CREP94 } & -0.2184 & 0.9478 & - \\
\hline & 0.7816 & $0.0521^{*}$ & - \\
\hline \multicolumn{4}{|c|}{ INDUSTRY = Computers/Communications } \\
\hline & AGE & TEN & TENCEO \\
\hline \multirow[t]{2}{*}{ CREP94 } & -0.1088 & 0.8205 & 0.2644 \\
\hline & 0.8374 & $0.0454 *$ & 0.6126 \\
\hline \multicolumn{4}{|c|}{ INDUSTRY = Consumer Durables } \\
\hline & AGE & TEN & TENCEO \\
\hline \multirow[t]{2}{*}{ CREP94 } & 0.9997 & 0.9856 & 0.9063 \\
\hline & $0.0148^{*}$ & 0.1079 & 0.2778 \\
\hline \multicolumn{4}{|c|}{ INDUSTRY $=$ Food/Drink/Tobacco } \\
\hline & AGE & TEN & TENCEO \\
\hline \multirow[t]{2}{*}{ CREP94 } & 0.9501 & -0.0933 & 0.3994 \\
\hline & $0.0498 *$ & 0.9067 & 0.6005 \\
\hline
\end{tabular}

\#Significant at $\mathrm{p}=0.10$

*Significant at $p=0.05$

Index:

CREP94 = Change in Fortune Corporate Reputation Index from 1990 to 1994

AGE $=$ Age of the CEO

TEN = Number of years of tenure in the company by the CEO

TENCEO = Number of years of tenure as CEO 
There was a positive relationship between tenure with the company and the change in overall corporate reputation in the capital goods and computers/communications industry. There was a positive relationship between age and the change in the overall corporate reputation of the firms in the consumer durables and the food/drink/tobacco industries. In contrast to the relationships presented in $\mathrm{Hy}$ potheses 2 through 4 , for firms that had a change in CEO, firms with a favorable overall corporate reputation had older CEOs who had more tenure within the organization.

\section{Conclusions and Suggestions for Future Research}

The results of this study highlight the complex relationship between the background characteristics of the CEO and the overall corporate reputation of the firm. The results show that, in general, the background characteristics of the CEO do impact the overall corporate reputation.

The surprising positive relationship between peripheral functional background and overall corporate reputation can be explained, in part, by recognizing the vast business experience of CEOs. This study has demonstrated that CEOs have exposure to multiple functional areas as they move up the corporate ladder. As a result, the broad functional training which CEOs are exposed to may reduce the resistance to implementing strategies which would enhance the overall corporate reputation of the firm.

The results of this study have shown the CEOs with a peripheral functional background have been able to compensate for their lack of "hands on" experience as it relates to the firm's core business. Through their exposure to different functions of the organization, peripheral CEOs have been able to incorporate proactive strategies in their decision making processes.

Of equal importance is the significant difference between the various industries over the time periods of the study. For firms that retained their CEO, there were significant inverse relationships in five of the six industries. This demonstrates that tenure, tenure as CEO, and age do play a role in the level of overall corporate reputations of organizations. Firms with CEOs who are younger and have less time vested in the organization are more likely to have a favorable overall corporate reputation. These results support the view of Hambrick and Fukutomi (1991) and Miller (1991) who state that as the CEO establishes him/herself in the CEO position, the CEO will firmly establish a rigid paradigm that will not be altered.

The results of firms that have had a change in their CEO during the sample time period also provide some very interesting observations. Contrary to what was proposed in Hypotheses 2 through 4, the results showed a positive relationship between overall corporate reputation and tenure and age. This could be explained, in part, through the type of CEO succession that took place. Of the four industries that had significant correlations, only two of the seventeen firms (11.7\%) 
had new CEOs from outside the firm. Therefore, CEO succession from within the company was the dominant form of succession. Even though insider succession is considered to support maintenance of the current strategic focus (Finkelstein and Hambrick, 1996), the CEO succession event will create the opportunity to consider alternative viewpoints (Hambrick and Futukomni, 1991). Since the new CEO is in the early "season" of his/her tenure, the CEO will accept adjustments in the existing paradigm. Therefore, the positive relationship between overall corporate reputation and tenure and age is the result of new CEOs with the willingness to accept alternative viewpoints. In addition, because the CEOs have a long length of tenure with the organization, they previously have acquired a high level of experience about the operations of the organization (Thomas and Simerly, 1994).

There are some limitations of this study that could be addressed in future research. The first limitation is the use of the Fortune Corporate Reputation Index. Although the authors believe that the Fortune Corporate Reputation Index is a valid proxy for overall corporate reputation, the authors realize that this index is only one measure of a very complex construct.

Another limitation is that the sample contains data from only two years. An extension of this paper would include the tracking of overall corporate reputation over a number of consecutive years in order to examine whether there are trends in the data, possibly between industries, which could be identified.

\section{References}

Barbosa, R. (1985). Innovation in a mature industry. Unpublished Ph.D dissertation, Columbia University: New York.

Beatty, R., \& Zajac, E. (1987). CEO change and firm performance in large corporations: Succession effects and manager shifts. Strategic Management Journal. 8, 305-317.

Caves, R., \& Porter, M. (1977). From entry barriers to mobility barriers. Quarterly Journal of Economics, $91,421-434$.

Chaganti, R., \& Sambharya, R. (1987). Strategic orientation and characteristics of upper management. Strategic Management Journal, 8, 393-401.

Dalton, D., \& Kesner, I. (1985). Organizational performance as an antecedent of inside/ outside chief executive succession: An empirical assessment. Academy of Management Journal, 28, 749-762.

Finkelstein, S., \& Hambrick, D. (1990). Top management team tenure and organizational outcomes: The moderating role of managerial discretion. Administrative Science Quarterly, 35, 484-503. 
Finkelstein, S., \& Hambrick, D. (1996). Strategic Leadership: Top Executive and Their Effects on Organizations. New York: West Publishing.

Fombrun, C., \& Shanley, M. (1990). What's in a name? Reputation building and corporate strategy. Academy of Management Journal, 33, 233-258.

Grimm, C. \& Smith, K. (1991). Management and organizational change: A note on the railroad industry. Strategic Management Journal, 12, 557-562.

Hambrick D., \& Mason, P. (1984). Upper echelons: The organization as a reflection of its top managers. Academy of Management Review, 9, 193-206.

Hambrick D., \& Fukutomi, D. (1991). The seasons of a CEO's tenure. Academy of Management Review, 16, 719-742.

Hammond, S., \& Slocum, J. (1996). The impact of prior firm financial performance on subsequent corporate reputation. Journal of Business Ethics. 15, 159-165.

Hoft, J., J. Hunger, \& Shrader, C. (1991). Characteristics of boards of directors and perceptions of corporate social responsibility: An examination of the Fortune survey. Journal of Business Strategies. 8, 77-85.

McGuire, J., J. Sundgren, \& Schneeweiss, T. (1988). Corporate social responsibility and firm financial performance. Academy of Management Journal, 31, 854-872.

Miller, D. (1991). Stale in the saddle: CEO tenure and the match between organization and environment. Management Science. 37, 34-52.

Thomas, A., R. Litschert, \& Ramaswamy, K. (1991). The performance impact of strategymanager coalignment: An empirical examination. Strategic Management Journal. 12 , 509- 522.

Thomas, A. \& Simerly, R. (1994). The chief executive officer and corporate social performance: An interdisciplinary examination. Journal of Business Ethics, 13, 959-968.

Song, J. (1982). Diversification strategies and the experience of top executives of large firms. Strategic Management Journal, 3, 377-380.

Vroom, V., \& Pahl, B. (1971). Relationship between age and risk-taking among managers. Journal of Applied Psychology. 55, 399-405.

Wiersema, M., \& Bantel, K. (1992). Top management team demography and corporate strategic change. Academy of Management Journal, 35, 91-121.

Wilson, R. (1985). Reputations in games and markets. In A.E. Roth (Ed.), Game-theoretic models of bargaining. New York: Cambridge University Press. 65-84. 
Wokutch, R. \& Spencer, B. (1987). Corporate saints and sinners: The effects of philanthropic and illegal activity on organizational performance. California Management Review, $29,62-77$.

\author{
Appendix \\ Major Industry Classifications \\ Aerospace/Defense \\ Business Services/Supplies \\ Capital Goods \\ Chemicals \\ Computers/Communications \\ Construction \\ Consumer Durables \\ Consumer Nondurables \\ Electric Utilities \\ Energy \\ Entertainment/Information \\ Financial Services \\ Food Distributors \\ Food/Drink/Tobacco \\ Forest Products/Packaging \\ Health \\ Insurance \\ Metals \\ Retailing \\ Transportation \\ Travel
}

Dr. Peter A. Stanwick received his Ph.D. in Strategic Management from Florida State University. He is an Assistant Professor in the Department of Management at Auburn University.

Dr. Sarah D. Stanwick received her Ph.D. in Accounting from Florida State University. She is an Assistant Professor in the School of Accountancy at Auburn University. 